Paper received: Nov 152019

Paper accepted: Jan 242020

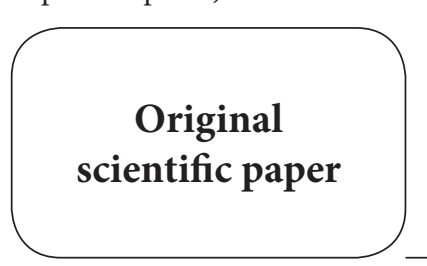

Aleksandra M. Mihajlović', Nenad R. Vulović, Milan P. Milikić

University of Kragujevac, Faculty of Education, Jagodina, Serbia

\title{
Using the Fangcheng method to develop pre-algebra concepts in primary-grade students
}

Summary: The aim of the study is to investigate the possibility for fourth grade students to use the adapted Fangcheng method as a tool for solving word problems. In the first part of the paper we give an overview of the Ancient Chinese Fangcheng method for solving systems of linear equations. The second part consists of the research methodology, results and discussion. We used the quasiexperimental one-group design with post-test only. The sample included 48 fourth grade students. The research had two phases, and at the end of each phase post-tests were conducted. In the first phase, all students participated in the intervention program, while the second phase included only those students who performed well on the first post-test. The study results indicate that students who show greater interest in mathematics successfully adopt procedures necessary for the performance of the Fangcheng method. The findings of the study cannot be applied to all students considering the fact that there are certain limitations, such as a small sample size and quasi-experimental design. Therefore, some further research should be performed with a larger sample of students. However, since there are not many empirical researches which explore the effects of applying the history of mathematics in math teaching, we believe that our study contributes to the field.

Keywords: Fangcheng method, systems of linear equations, primary school mathematics, fourth grade students.

1 aleksandra.mihajlovic@gmail.com

Copyright $\odot 2020$ by the authors, licensee Teacher Education Faculty University of Belgrade, SERBIA.

This is an open access article distributed under the terms of the Creative Commons Attribution License (CC BY 4.0) (https://creativecommons.org/licenses/by/4.0/), which permits unrestricted use, distribution, and reproduction in any medium, provided the original paper is accurately cited. 


\section{Introduction}

Introducing history of mathematics in classrooms might help students understand that mathematics is a vivid discipline with rich cultural and historical roots in the practical life of people (Abah, 2017). The idea of integrating contents of the history of mathematics in a math class is not new (Fried, 2001; Dejić \& Mihajlović, 2014). There is a great number of works which offer various discussions on why and how to use the history of mathematics in mathematics teaching and learning (Mihajlović \& Milikić, 2019). Researchers stress many benefits of using history of mathematics in mathematics education, such as: laying foundation for better understanding of mathematics; contributing to the development of students' mathematical thinking; sharpening problem-solving skills; helping students establish mathematical connections; providing a context for problems and ideas; suggesting alternative approaches to problem solving; showing the relationships between different ideas, definitions, and applications; highlighting interaction between mathematics and society; making mathematics more interesting and approachable; increasing students' motivation and developing positive attitudes toward learning; encouraging multicultural approaches; overcoming students' fear of mathematics; giving students a historical role-model; giving a human dimension to mathematics and mathematical knowledge (Fried, 2001; Liu, 2003; Wilson \& Chauvot, 2000). Many studies and research indicate that it is very important for preservice mathematics teachers to be familiar with the genesis of mathematical concepts and statements (Schubring et al., 2000; Dejić \& Mihajlović, 2014). Didactic skills of teachers can be improved by analyzing old sources and past obstacles in the historical development of mathematics, since these might explain the difficulties students face when forming some concepts and ideas (Gulikers \& Blom, 2001; Mihajlović \& Milikić, 2019). Therefore, history of mathematics might serve as a guideline for teaching mathematics
(Liu, 2003). The order of the topics in a math curriculum is determined mostly in accordance with historical development of some mathematical ideas (Katz, 1993). It is known that students very often form certain mathematical concepts in the way similar to the way these concepts have been formed throughout the history of civilization: direct counting, observation of the real objects, measuring, etc. (Dejić \& Mihajlović, 2014). Evidently, students do not go through the entire process of the historical development (which sometimes lasted for centuries) in learning these mathematical concepts, but use shorter routes facilitated by appropriate methodological transformation of the mathematical contents.

In this paper, we discuss the possibilities of introducing some pre-algebra concepts, such as systems of linear equations, to primary-grade students by using an ancient Chinese method. Considering the fact that there are not many empirical researches that explore the benefits of using the content of history of mathematics in a math class (Jankvist, 2009), we believe our research will significantly contribute to the field of study.

\section{The Nine Chapters on the Art and Calculation - the Fangcheng method}

The Jiu Zhang Suan Shu or The Nine Chapters on the Art and Calculation represents one of the most important and most influential mathematical works in the long history of China (Schwartz, 2008). It is a collection of 246 mathematical problems within different topics (measurement, architecture, engineering, surveying) which are grouped into 9 chapters (Siu, 1993). The authors and date are not known, but it is believed that it was composed by several generations of scholars from the tenth to the second century BC (Yuan, 2012). The original version of the Nine Chapters contained rules and algorithms, but there were no formal proofs or explanations (Schwartz, 2008). In $263 \mathrm{AD}$, one of the great- 
est mathematicians of ancient China, Liu Hui (225295) edited and published the book. Furthermore, Liu Hui provided written commentaries and justifications for the used techniques. The eighth chapter of the book, entitled Fangcheng is dedicated to solving some real-life problems, such as calculating the yields of rice, prices of different products and numbers of animals (Yuan, 2012). It is based on practical applications to real life situations. It contains eighteen riddles/problems dealing with systems of linear equations and their solution techniques are presented. The problems in this chapter were set up in the way which is similar to how we would today formulate them in Linear algebra, using $n$ equations with $n$ unknowns (Mihajlović \& Milikić, 2019). Out of 18 problems, 17 can be formulated as well-defined linear equations (with variables ranging from 2 to $5)$, while one of the problems represents an underdetermined linear system (5 equations and 6 variables). The Fangcheng method, the translation of which literally means "Method of rectangular arrays", deals with the solution of simultaneous linear equations with two to five unknowns by placing them in a table, and operating with columns in a way identical to the row transformations of the matrix algebra (Joseph, 2011).

Chinese computation procedure was performed with a set of rods on a grid called counting board. Various numbers were represented by various rod configurations. The rod numerals were put down on the counting board in the way identical to the one we use to form the matrix for solving equations with multiple unknowns. The detailed instructions for solving problems required setting up and manipulation of rod numeral rectangular arrays. The counting board allowed the Chinese to easily distinguish between different variables (Swetz, 1979). The analysis of these manipulations implies that they used the same principle, which was developed fifteen hundred years later by famous German mathematician Carl Friedrich Gauss (1777-1855), known as the Gaussian elimination. Although a variant of Gauss' elimination procedure was proposed earlier by another mathematician, Tobias Mayer (1723-1762), this way of tackling systems of linear equations had not been found in any other mathematical tradition until the development of modern mathematics (Joseph, 2011).

We will illustrate the Fangcheng method in solving the first problem in Chapter 8, which involves harvesting three different grades of rice.

The problem. Now given 3 bundles of top grade paddy, 2 bundles of medium grade paddy, [and] 1 bundle of low grade paddy. Yield: 39 dou of grain. 2 bundles of top grade paddy, 3 bundles of medium grade paddy, [and] 1 bundle of low grade paddy, yield 34 dou. 1 bundle of top grade paddy, 2 bundles of medium grade paddy, [and] 3 bundles of low grade paddy, yield 26 dou. Tell: how much [dou] does one bundle of each grade yield? (Schwartz, 2008: 11)

The problem can be represented with rods on the counting board (on the left), as well as with Arabic numerals (on the right), as given in Figure 1.

\begin{tabular}{rcc|}
\hline 1 & II & III \\
II & III & II \\
III & 1 & 1 \\
$=1$ & $\equiv\|I\|$ & $\equiv \equiv$ \\
\hline
\end{tabular}

(I)

\begin{tabular}{|rcr|}
\hline 1 & 2 & 3 \\
2 & 3 & 2 \\
3 & 1 & 1 \\
26 & 34 & 39 \\
\hline
\end{tabular}

Figure 1. The counting board and representation of Arabic numerals (Martzloff, 2006).

If we used the familiar algebraic notation, then the previous representation would be equivalent to the next set of equations

$$
\left.\begin{array}{l}
3 x+2 y+z=39 \\
2 x+3 y+z=34 \\
x+2 y+3 z=26
\end{array}\right\}
$$

However, we will continue solving the problem with the use of rods and counting board. After performing the series of multiplications and subtractions with the appropriate columns, the initial "rectangular array" is reduced in tabular form as illustrated in the Figure 2. 


\begin{tabular}{|ccc|}
\hline 1 & 6 & 3 \\
2 & 9 & 2 \\
3 & 3 & 1 \\
26 & 102 & 39 \\
\hline
\end{tabular}

\begin{tabular}{|ccc|}
\hline 1 & 0 & 3 \\
2 & 5 & 2 \\
3 & 1 & 1 \\
26 & 24 & 39 \\
\hline
\end{tabular}

\begin{tabular}{|ccc|}
\hline 3 & 0 & 3 \\
6 & 5 & 2 \\
9 & 1 & 1 \\
78 & 24 & 39 \\
\hline
\end{tabular}

\begin{tabular}{|ccc|}
\hline 0 & 0 & 3 \\
4 & 5 & 2 \\
8 & 1 & 1 \\
39 & 24 & 39 \\
\hline
\end{tabular}

\begin{tabular}{|ccc|}
\hline 0 & 0 & 3 \\
20 & 5 & 2 \\
40 & 1 & 1 \\
195 & 24 & 39 \\
\hline
\end{tabular}

\begin{tabular}{|ccc|}
\hline 0 & 0 & 3 \\
0 & 5 & 2 \\
36 & 1 & 1 \\
99 & 24 & 39 \\
\hline
\end{tabular}

Figure 2. Representation of the solution procedure on the counting board.

If we pay closer attention, we see that the matrix of the system is actually reduced to a triangular form. By using simple division, the value of one of the unknowns can be determined ( $\mathrm{z}=36 / 99)$, and the other two unknowns can be found using the successive substitutions. Martzloff indicates that the Fangcheng technique is "visibly nothing other than Gauss's method" (Martzloff, 2006: 254), although Gauss's work has little to do with the work of Chinese authors.

\section{Using the Fangcheng method to develop pre-algebra concepts in primary-grade students}

From the pedagogical viewpoint, the history of mathematics has a potential to be used in math classes (Dejić \& Mihajlović, 2014). As Costa et al. (2015) indicate, it can contribute to the development of some pre-algebra concepts, such as systems of linear equations, unknowns and matrices. These authors performed a case study about the use of a simplified form of the Fangcheng method for solving a system of linear equations by a gifted 10 year old student. The results of the study indicated that it was possible to learn the Fangcheng method at a much earlier age compared to the age when solving systems of linear equations is usually taught. In Serbia, students in the lower primary school grades learn how to solve some simple linear equations with one unknown, and how to model word problems into these equations (Mihajlović \& Milikić, 2019). They do not learn how to solve systems of linear equations until the $8^{\text {th }}$ grade of primary school. Nevertheless, in order to solve some complex word problems, which require the knowledge of the more advanced methods (such as systems of linear equations), primary school students (third and fourth grade) use certain mathematical models which allow them to transform these problems into simpler ones. The most commonly used models in Serbian primary schools are: the line segment model (which corresponds to the bar model), the rectangle area model and the false assumption method. For example, the line segment model can be defined as a pictorial representation of a number in a form of a line segment. This model helps students understand the number relationships as well as which operations should be used to solve a word problem. It also enables them to visually represent known and unknown quantities, as well as the relation between both the known and unknown, and between two and more unknowns. This model is usually used when there is one of the following relations between unknown variables $a$ and b: (a) $a$ is greater than $b$ by $n$, or (b) $a$ is $n$ times as large as $b$. The rectangle area mod$e l$ is used when one variable in the word problem can be expressed as a product of two other variables. The basic idea of the model is to represent the relation of three variables through the relation between the sides of the rectangle and its area. If one side of the rectangle is increased, the other side should be decreased in order for the area to remain the same. By using graphical representation in both of models, the system of two linear equations with two unknowns is transformed into the process of solving the equation with one unknown.

The Fangcheng method is based on adequate visual representation of numerals on the counting board and involves only basic calculations, such as subtraction and multiplication. Considering these and the study performed by Costa et al. (2015), we believe that primary grade students can understand 
and use the Fangcheng method to solve some word problems that involve systems of linear equations.

\section{Research methodology}

The main aim of the study was to investigate the possibility for the fourth grade students to use an adapted Fangcheng method as a tool for solving word problems. The first research task was to determine if the fourth grade students were able to learn, understand, and use the Fangcheng method when solving the systems of linear equations with two unknowns. The second research task was to examine if students were able to learn, understand, and use the same method in solving the systems of linear equations with three unknowns.

A quasi-experimental one-group design with post-test only was used due to the fact that the study required the observation of a single group during and after the intervention (Privitera \& AhlgrimDelzell, 2018). In some situations, in which there is a much specific background knowledge about how the dependent variable might behave, the onegroup design with post-test only has merit (Shadish et al., 2002). In our research, the pre-test could not be monitored since no student had had previous experience in using the presented method for solving systems of linear equations. Furthermore, there was no justified reason to include a control group since the comparison would not be possible considering that the contents presented to the experimental group were not usually taught in first four primary school grades, and sometimes not until the eighth grade. Hence, students in the control group would not be able to solve the test examining their understanding of the new method and contents, for traditionally they were not taught about these.

Sample. The research sample involved 48 fourth grade students from two different classes of the primary school Boško Djuričić in Jagodina. The primary school and classes were randomly chosen among other primary schools in Jagodina. The study was conducted at the end of the school year, in June 2019 and it took two weeks. There were 27 male students and 21 female students. All students were 10 years old. The general students' Mathematics achievements are presented in Table 1 and then in Table 2, in regard to the gender.

Table 1. Distribution of Mathematics grades at the end of the fourth grade.

\begin{tabular}{cccccc}
\hline Grades & 5 & 4 & 3 & 2 & IEP $^{2}$ \\
\hline Frequencies & 58,33 & 31,26 & 6,25 & 2,08 & 2,08 \\
\hline
\end{tabular}

Table 2. Distribution of Mathematics grades at the end of the fourth grade in regard to the gender.

\begin{tabular}{cccccc}
\hline Grades & 5 & 4 & 3 & 2 & IEP \\
\hline boys & 17 & 7 & 2 & 0 & 1 \\
\hline girls & 11 & 8 & 2 & 2 & 0 \\
\hline
\end{tabular}

The mean mathematics grade for all students (except for the students that study by IEP) was 4.49 $(\mathrm{SD}=0.72), 4.58$ for boys $(\mathrm{SD}=0.64)$, and 4.38 for girls $(\mathrm{SD}=0.80)$.

Procedure. The treatment involved two phases. Each phase lasted two classes, within a seven-day interval.

The first phase of the study included all students of two fourth grade classes. The aim of this stage was to introduce the students to a revised version of the Fangcheng method of solving a system of two equations with two unknowns.

The second phase of the study included students who had correctly done at least two tasks after the first phase. The objective of this phase was the adoption of the Fangcheng method of solving a system of three linear equations with three unknowns.

2 The Individualized Educational Plan developed to ensure that a child with a disability received specialized instruction. 
Instrument. During the study, the tasks designed by the authors were used in both phases. The objective of the tasks was to adopt the method of solving a system of two equations with two unknowns in the first phase, that is, a system of three equations with three unknowns in the second phase. The degree of understanding the content the students were dealing with was determined by the tests after the first (appendix 2) and second (appendix 4) phases of the study. The processing of the obtained data was done by standard qualitative analysis.

\section{Results and Discussion}

Although the content the students were introduced to during the study was new to them, they showed an interest in adopting new contents in the class, which was reflected in their activities, their willingness to comment, suggest and conclude, as well as to ask questions about the ambiguities encountered during their work.

The introduction to the first phase of the study was a task depicting two situations of maintaining balance on virtual scale by adding or subtracting objects of equal masses on the scale plates. The aim of both situations was for the students to come to the following conclusions:

- if we add or subtract equal masses of objects to the balanced scale plates, the scale will still remain balanced;

- if the mass of an object from one of the plates, which are in balance, gets doubled, tripled, etc. ... then we must increase the mass of the object on the second plate just as many times in order to keep the scale balanced;

Such considerations served to draw mathematical conclusions:

- if we add or subtract the same number to the left and right sides of equality, the equality will continue to apply;
- if we multiply the left and right sides of equality by the same number, the equality will continue to apply.

These procedures are analogous to those required by students to perform operations with rows or columns in a table.

After the introductory part, the tasks completed in the first phase (appendix 1) are designed so that students should:

- in the first task, learn how to form a Fangcheng $2 \times 2$ table, subtract values of one column from the values of the other column, form a column with one zero in the first two rows, determine the value of one variable and, finally, determine the value of the other variable;

- in the second task, practice the procedures from the first task and become acquainted with the successive subtraction of values in one column from the values in the other column, and as an alternative, to form a zero in the table by determining the least common multiple in the same row, multiply the columns by corresponding numbers, and then subtract values of one column from the values of the other column;

- in the third task, practice the procedures shown in the first two tasks.

When writing down the values in the tables, we used the left-to-right orientation, as this notation is common to students, much like Costa et al. (2015).

That this way of working with students has had a good effect is shown by the results obtained by testing.

In the first task of the test, students were given a text-based system of two equations with two unknowns and the initial table was fully formed. The number values in one row of the table were equal, and the solution was obtained with a single subtraction of the corresponding values from the columns, after which the values of the variables were determined. Students' success in each part of the assignment is given in the Table 3. 
Table 3. Students' success in the first task.

\begin{tabular}{cccc}
\hline & $\begin{array}{c}\text { Accurately } \\
\text { subtracted } \\
\text { correspond- } \\
\text { ing values } \\
\text { from the } \\
\text { columns }\end{array}$ & $\begin{array}{c}\text { Accurately } \\
\text { determined } \\
\text { value of one } \\
\text { unknown }\end{array}$ & $\begin{array}{c}\text { Accurately } \\
\text { determined } \\
\text { value of } \\
\text { both un- } \\
\text { knowns }\end{array}$ \\
\hline $\begin{array}{c}\text { Number of } \\
\text { students }\end{array}$ & 42 & 36 & 18 \\
\hline
\end{tabular}

The first step in determining the solution, accurate subtracting of values from columns and forming zero in one column, was done by a large number of students. One cannot identify a specific category of students who did not successfully complete this part of the task because among those who did not do this step well, was a student with a grade of 5. It is interesting that a student who works according to the IEP, did the first step well.

The second step in solving the first task was to determine the value of one unknown. This step was done accurately by $75 \%$, while the last step, replacing one obtained value in the appropriate equation and determining the other unknown, was successfully done by $37.5 \%$ of the students.

We notice a global characteristic of all student works in this and in the following tasks. Working with students in the class, the emphasis was not on the mathematical strictness of the writing in determining unknown values, but on the correctness of data presentation. The procedure for determining the unknown values from the table will be illustrated to students by the example of task 2 from the class (Figure 3).

\begin{tabular}{|c|c|c|}
\hline 2 white boxes & 1 white box & $\begin{array}{l}4 \text { blue boxes } \\
5 \text { white boxes }\end{array}$ \\
\hline 18 cookies & 9 cookies & 77 cookies \\
\hline $\begin{array}{l}4 \text { blue boxes } \\
45 \text { cookies }\end{array}$ & 4 blue boxes & 1 blue box \\
\hline 77 cookies & 32 cookies & 8 cookies \\
\hline
\end{tabular}

Figure 3. Writing and method of determining unknown values.
However, although the students determined the data during the class in the presented way, when it came to testing, all the students who came to the point when it was necessary to determine the value of the unknown, abridged the writing immediately by writing down the value of one unknown and verbally performing computational operations to determine the other unknown (Figure 4).

The second test task required of students to independently mark the values and enter data in a table. There was a row in this table as well, in which there were two equal numbers, but the order of listing the variables in the task concept was different, so the students had to pay attention to what position in the table they were writing numbers on. Students' success in each part of the task is given in the Table 4 .

We see that the order in which the variables in the assignment were listed caused $18.75 \%$ of the students to write wrong values in the table, which is conditioned by the linearity of reading the assignment and not paying attention to the identicality of the values being entered in the same row. Almost equal number of students failed to successfully subtract the corresponding values from the columns. Characteristically, out of the students who did not take a single step in the first task, only one failed to tabulate, and 3 others failed to complete the required subtraction of the values from the columns as well. This leads to the conclusion that very few students failed to understand all parts of the technique used in the class.

Table 4. Students' success in the second task.

\begin{tabular}{|c|c|c|c|c|}
\hline & $\begin{array}{l}\text { Accurate- } \\
\text { ly entered } \\
\text { values in } \\
\text { the table }\end{array}$ & $\begin{array}{l}\text { Accu- } \\
\text { rately } \\
\text { subtract- } \\
\text { ed corre- } \\
\text { sponding } \\
\text { values } \\
\text { from the } \\
\text { columns }\end{array}$ & $\begin{array}{l}\text { Accu- } \\
\text { rately de- } \\
\text { termined } \\
\text { value } \\
\text { of one } \\
\text { unknown }\end{array}$ & $\begin{array}{l}\text { Accu- } \\
\text { rately de- } \\
\text { termined } \\
\text { value } \\
\text { of both } \\
\text { un- } \\
\text { knowns }\end{array}$ \\
\hline $\begin{array}{c}\text { Number } \\
\text { of stu- } \\
\text { dents }\end{array}$ & 39 & 29 & 25 & 16 \\
\hline
\end{tabular}



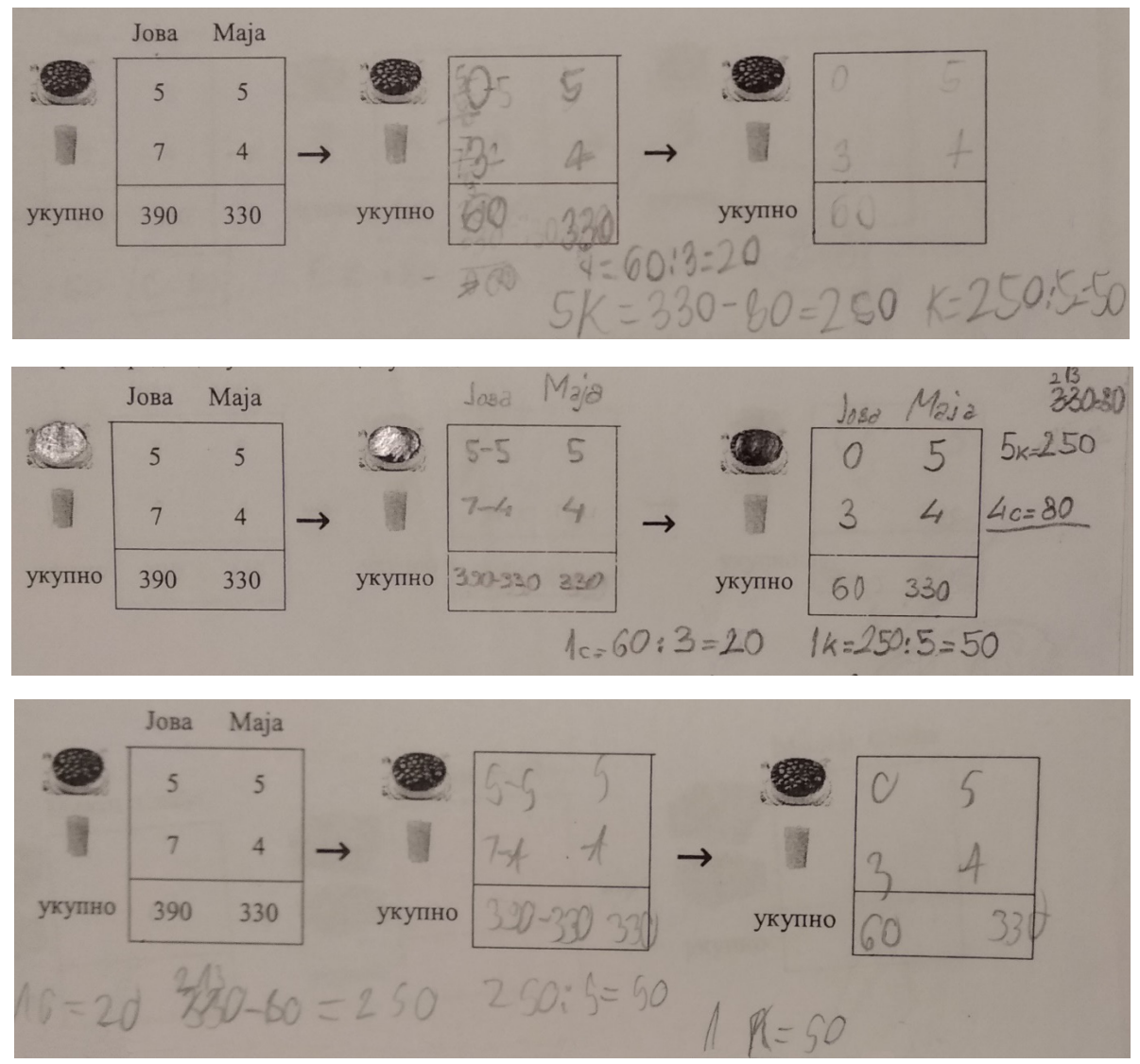

Figure 4. Methods to calculate unknown values.

Although the number of students who successfully determined only one variable is smaller than in the previous task, the approximate number of students managed to completely do this task as well. The number of students who accurately determined one variable is lower due to the computational errors that students made while working.

The third task of the test, unlike the previous tasks, did not have the ready-made values in the row with which students could immediately determine the value of one variable by one subtraction of values from columns, that is, it was necessary to perform multiple subtraction of values from columns of the table. The example of task 2, which was done with the students in the class, illustrates the shown method of writing multiple subtraction of values from the columns of the table (Figure 5).

Although the original Fangcheng method is based on the described column subtraction process, in order to simplify the procedure, the students were explained that it was possible to get zero in one row by specifying one common multiple in a row and then by multiplying the columns by the corresponding numbers to obtain the required equal values in a row (Figure 6).

Twelve students did not attempt to do the third task, while 3 students did not create a good initial table. Students' success in each part of the third task is given in the Table 5. 


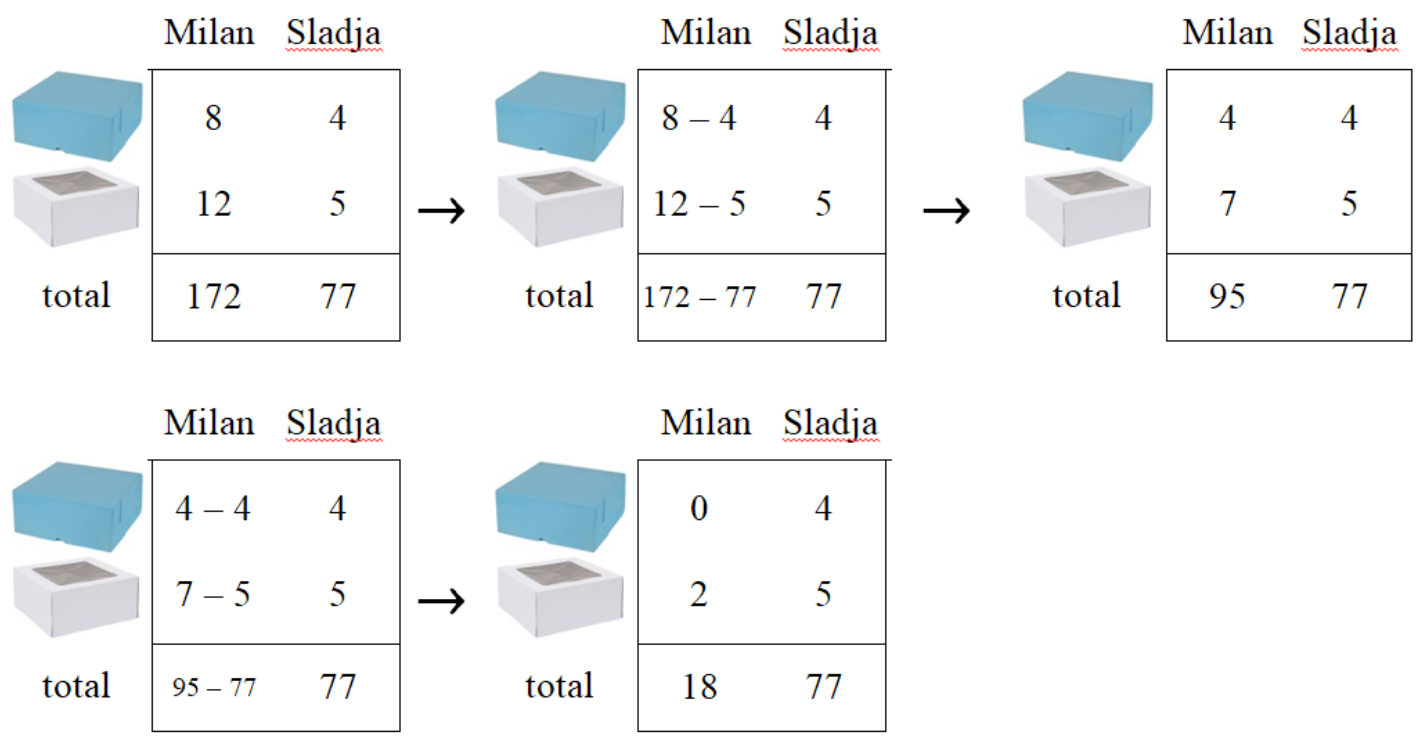

Figure 5. An example of the table layout and method for writing data.

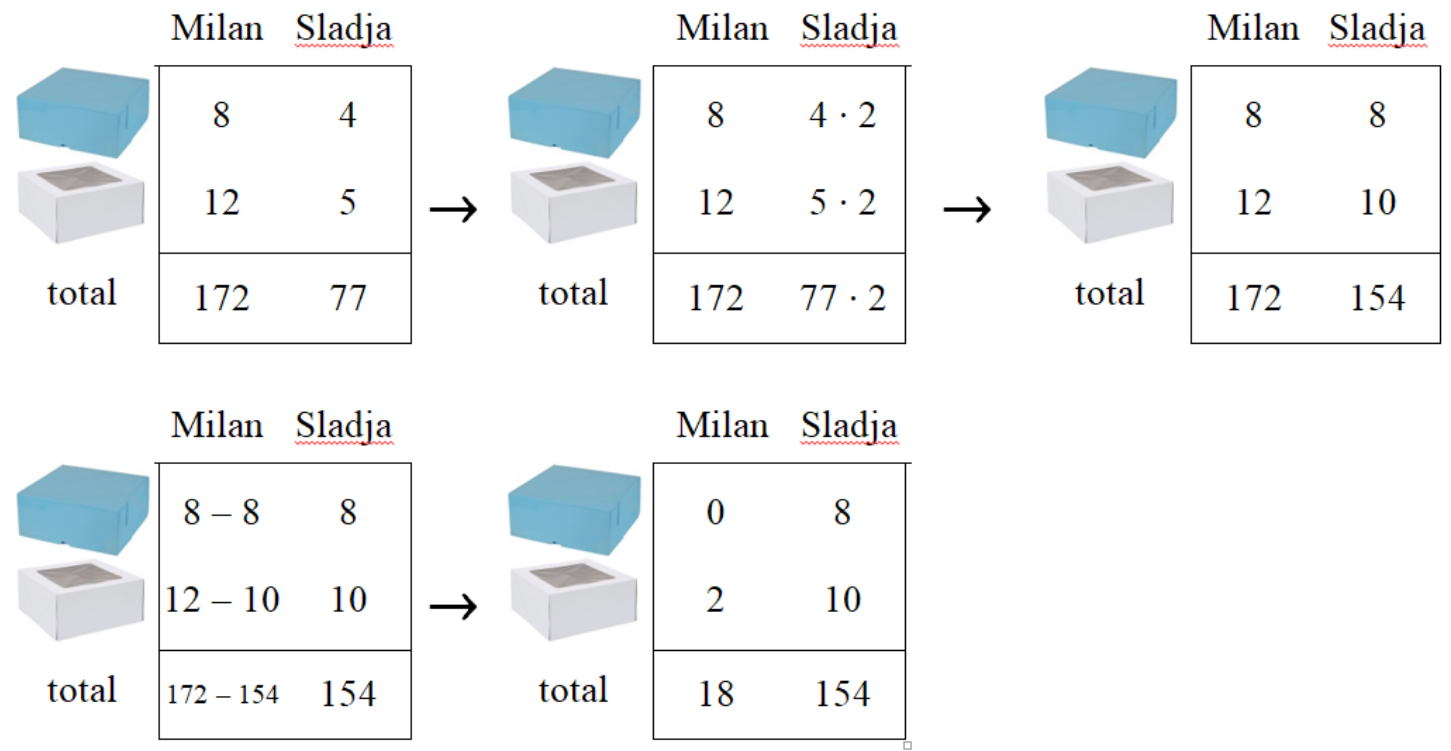

Figure 6. Another method to get a zero in a table.

Table 5. Students' success in the third task.

\begin{tabular}{lcccc}
\hline & $\begin{array}{c}\text { Accurately entered } \\
\text { values in the table }\end{array}$ & $\begin{array}{c}\text { Accurately obtained } \\
\text { zero in one column }\end{array}$ & $\begin{array}{c}\text { Accurately deter- } \\
\text { mined value } \\
\text { of one unknown }\end{array}$ & $\begin{array}{c}\text { Accurately deter- } \\
\text { mined value } \\
\text { of both unknowns }\end{array}$ \\
\hline Number of students & 33 & 14 & 12 & 7 \\
\hline 80 & & & & 7 \\
\hline
\end{tabular}


Students' lower success rate in this task is noticeable, and the reason for this is precisely their inability to figure out the transformation of tables in the process of obtaining a zero in one column. Out of 33 students who successfully formed the table, 17 got zero in columns by multiplying the columns, while 13 did it by multiple subtractions. It should be noted that three students continued their work by dividing values in one column, although there was no talk of this method of work in the class. There are obvious common computational errors made by students, as well as errors in which, when multiplying or subtracting values in the table, they multiply or subtract the corresponding values of the first two rows, while leaving the last row unchanged.

The testing after the first phase served as an entrance test for the second phase, in which all students who did well in at least two of the three tasks participated. Although 16 students met this requirement, 14 students attended the class. Only one student had a grade of 4 and all others had a grade of 5 in math. Of the 14 students, 4 were female and the rest were male. In an individual interview with the teachers of the two school classes, we found that all students who participated in the second phase showed a particular interest in math and all had successfully participated in math competitions in the previous two years.

As the second phase envisages the adoption of the three-equation method with three unknowns, the tasks performed in this phase (appendix 3) are selected so that students:

- repeat the basic rules adopted in the first phase;

- adopt the formation of Fangcheng $3 \times 3$ tables;

- notice a method to reduce a $3 \times 3$ table to a $2 \times 2$ case;

- adopt a procedure for determining unknown values.

The testing of students after conducting the second phase of the study showed a high degree of understanding of the contents that were done. The students' success in solving the test assignment where there is a text-based system of three equations with three unknowns using the Fangcheng method is given in the Table 6 .

Table 6. Students' success in the second test.

\begin{tabular}{ccccccc}
\hline & $\begin{array}{c}\text { Accurately } \\
\text { formed table } \\
3 \times 3\end{array}$ & $\begin{array}{c}\text { Accurately } \\
\text { formed reduced } \\
\text { table } 2 \times 2\end{array}$ & \multirow{2}{*}{$\begin{array}{c}\text { Accurately } \\
\text { solved table } 2 \times 2\end{array}$} & \multicolumn{3}{c}{$\begin{array}{c}\text { Accurately determined value } \\
\text { of the variable }\end{array}$} \\
\cline { 6 - 8 } $\begin{array}{c}\text { Number of } \\
\text { students }\end{array}$ & 14 & 12 & 11 & 9 & 7 & 6 \\
\hline
\end{tabular}

All students successfully drew a $3 \times 3$ table, marked the rows and columns, and accurately entered the numerical values in it.

Reducing the $3 \times 3$ table to a $2 \times 2$ table is explained to the students in such a way that it is necessary to get two zeros in one row, by multiple subtracting or multiplying, then by subtracting the cor- responding values from the columns. Based on the results, we can see that this step was successfully understood by the students, and as an illustration of the whole procedure we present the work of one of the students (Figure 7). 


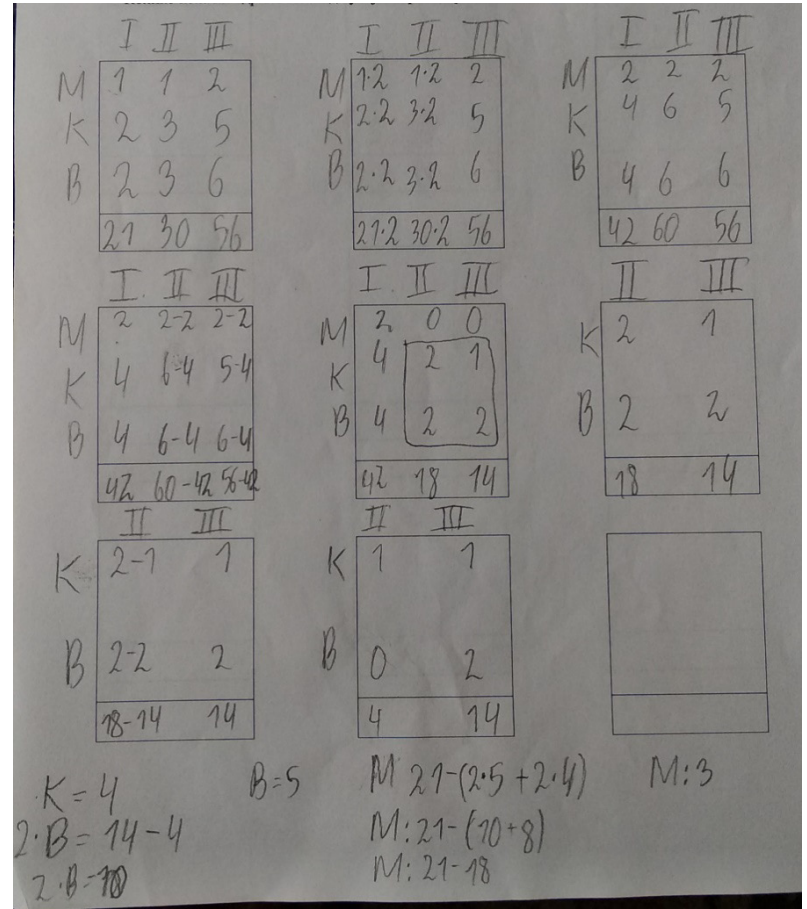

Figure 7. A student's method of writing a solution.

During the examination of the students' work, we noticed the work in which the student got two zeros in one column of the table, and then correctly completed the task, although this procedure of forming a $2 \times 2$ table differs from that shown in the class (Figure 8).

Further work with the $2 \times 2$ table was as good for most students as we expected it to be, but the results obtained in the Table 6 were conditioned by the computational errors that students made when calculating. Of the 6 students who accurately specified all the required information, 5 were male and 1 was female. Characteristically, male students made computational errors to a greater extent, and all female students successfully determined the value of at least one unknown.

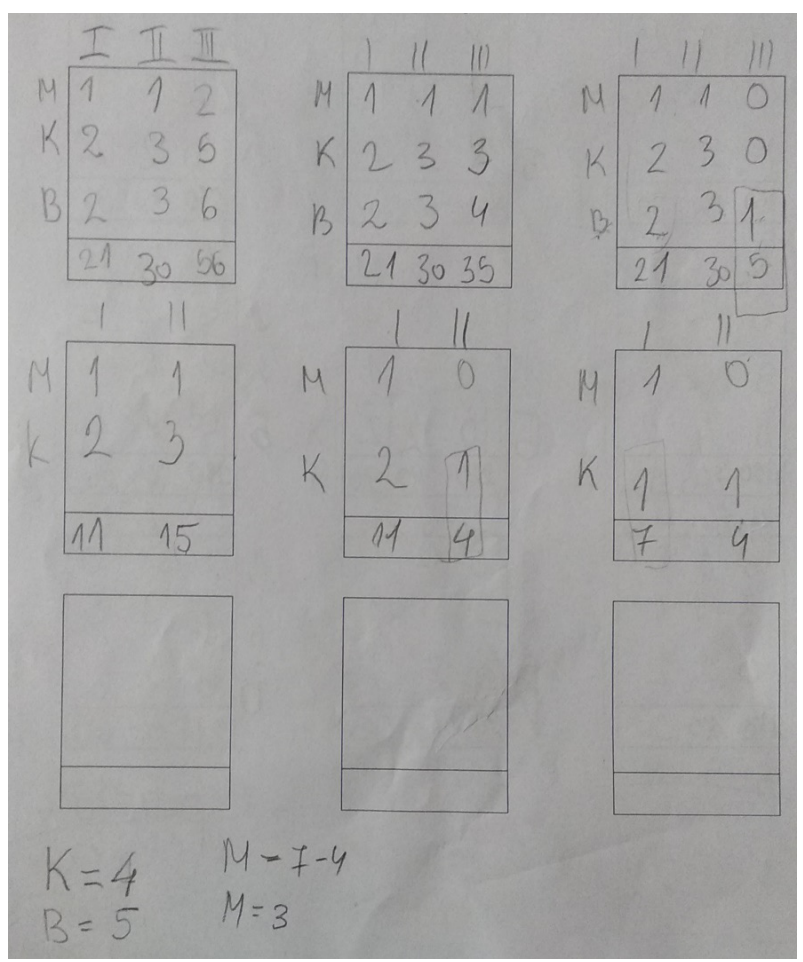

Figure 8. Another method of obtaining zeros in a table and determining a solution.

\section{Conclusion}

Based on the quantitative and qualitative analysis of the fourth grade students' tasks, we can conclude that they use the Fangcheng method without any difficulties when solving text-based systems of linear equations with two unknowns within the given formed initial table. Difficulties arise when students need to mark the values and form a table on their own, which is often conditioned by the linearity of reading the assignment and by not paying attention to the ratios between the values.

A large number of students manages to understand the technique used, but due to frequent computational errors, they are unable to accurately determine the values of the unknowns. Among the students who are able to apply the Fangcheng method in solving a system of linear equations with two 
unknowns, majority have excellent grades in mathematics, while a gender difference in favor of boys is also noticeable. However, since there were more boys than girls in the initial sample, we cannot generalize this statement.

The results of our study are in compliance with the results of the study conducted by Costa et al. (2015). Students who have shown a particular interest in mathematics are able to understand and use the Fangcheng method in solving text-based systems of linear equations with three unknowns. Differences in the success rate in solving the tasks that we found to exist, indicate that more attention should be paid to developing student concentration and systematics, in order to reduce computational errors when calculating values of unknowns.

The findings of the study cannot be generalized to all students considering the fact that there are certain limitations, such as a small sample size and quasi-experimental design. Although the sample of students surveyed showed interest in adopting new contents, it would be significant in subsequent studies to use a larger sample and examine whether and to what extent it is possible to adopt the Fangcheng method of solving a linear equation system with two and three unknowns.

The history of mathematics offers teachers many guidelines on how certain mathematical contents can and should be taught. However, there should be more empirical researches in order to explore the effects of using the history of mathematics in mathematics teaching. In this regard, it would be important in future studies to examine the views of teachers as to whether they apply segments of the history of mathematics in their teaching work, for what purpose, in what parts of the class, whether their application sufficiently arouses students' interest.

\section{References}

- Abah, A. J. (2017). Viewing basic math through the lens of history: Undergraduates' reflective learning in a history-augmented mathematics classroom. Waikato Journal of Education, 22 (4), 33-48.

- Costa, C., Alves, J. M. \& Guerra, M. (2015). Ancestral Chinese method for solving linear systems of equations seen by a ten-years-old Portuguese child. In: Barbin, E., Jankvist, U. T. \& Kjeldsen, T. H. (Eds.). History and epistemology in mathematics education (169-182), The Proceedings of the Seventh European Summer University ESU7, 14-18. 7. 2015. Copenhagen: Aarhus University, Danish School of Education.

- Dejić, M. \& Mihajlović, A. (2014). History of mathematics and teaching mathematics. Teaching Innovations, 27 (3), 15-30. DOI: 10.5937/inovacije1403015D

- Fried, M. N. (2001). Can mathematics education and history of mathematics coexist? Science \& Education, 10, 391-408.

- Gulikers, I. \& Blom, K. (2001). 'A historical angle', a survey of recent literature on the use and value of history in geometrical education. Educational Studies in Mathematics, 47, 223-258.

- Jankvist, U. T. (2009). On empirical research in the field of using history in mathematics education. Revista latino americana de investigación en matemática educativa, 12 (1), 6-101.

- Joseph, G. G. (2011). The crest of the peacock. Non-European roots of Mathematics (3 ${ }^{\text {rd }}$ edition). Princeton, New Jersey, USA: Princeton University Press.

- Katz, V. J. (1993). Using the history of calculus to teach calculus. Science \& Education, 2 (3), $24-49$.

- Liu, P. (2003). Do Teachers Need to Incorporate the History of Mathematics in their Teaching? The Mathematics Teacher, 96 (6), 416-421. 
- Martzloff, J. C. (2006). A history of Chinese mathematics. Berlin, Germany: Springer-Verlag Berlin Heideberg.

- Mihajlović, A. \& Milikić, M. (2019). Fangcheng method as a tool for developing pre-algebra concepts in primary grade students. In: Lawrence, S., Mihajlovic, A. \& Djokic, O. (Eds.). History of Mathematics in Mathematics Education (52-57). The Proceedings of the Training Conference History of Mathematics in Mathematics Education. 26-30. 10. 2018. godine. Jagodina: University of Kragujevac, Faculty of Education.

- Privitera, G. J. \& Ahlgrim-Delzell, L. (2018). Research methods for Education. Thousand Oaks, CA: SAGE Publications.

- Schwartz, R. (2008). A classic from China: The Nine Chapters. The Right Angle, 16 (2), 8-12.

- Schubring, G. (2011). Conceptions for Relating the Evolution of Mathematical Concepts to Mathematics Learning-Epistemology, History, and Semiotics Interacting: To the Memory of Carl Menger (1902-1985). Educational Studies in Mathematics, 77 (1), 79-104.

- Shadish, W. R., Cook, T. D. \& Campbell, D. T. (2002). Experimental and quasi-experimental design for generalized causal inference. Boston, MA, US: Houghton, Mifflin and Company.

- Siu, M. K. (1993). Proof and pedagogy in Ancient China: Examples form Liu Hui’s commentary on Jiu Zhang Suan Shu. Educational Studies in Mathematics, 24, 345-357.

- Swetz, F. (1979). The evolution of mathematics in Ancient China. Mathematics Magazine, 52 (1), 10-19.

- Yuan, Y. X. (2012). Jiu Zhang Suan Shu and the Gauss algorithm for linear equations. Documenta Mathematica, Extra Volume ISMP, 9-14.

- Wilson, P. S. \& Chauvot, J. B. (2000). Who? How? What? A strategy for using history to teach mathematics. Mathematics Teacher, 93 (8), 64-645. 


\section{Appendix}

\section{Appendix 1}

\section{Tasks used for work with students in the first phase of the study}

Task 1. Zoran measured 3 apples and 4 pears and obtained a mass of $1250 \mathrm{~g}$. Mila measured 3 apples and 5 pears and obtained a mass of $1450 \mathrm{~g}$. All apples have the same mass and all pears have the same mass. Determine the mass of one apple and the mass of one pear.

Task 2. Milan and Sladja packed the cookies in blue and white boxes. Milan packed 184 cookies in 8 blue and 12 white boxes. Sladja packed 82 cookies in 4 blue and 5 white boxes. Each blue box has the same number of cookies and each white box has the same number of cookies (the number of cookies in blue and white boxes does not have to be the same). How many cookies were put in each blue box and how many in each white box?

Task 3. Žarko wrote down three of the same numbers $a$ and two of the same numbers $b$. The sum of all the numbers that Žarko wrote down is 1892. Mirka wrote down the number $a$ four times, and the number $b$ three times. The sum of the numbers Mir$\mathrm{ka}$ wrote is 2662 . Determine the values of the numbers $a$ and $b$.

\section{Appendix 2}

\section{Tasks on the test after the first phase of the study}

Task 1. Jova and Maja bought cookies and juices for their friends. Jova bought 5 cookies and 7 juices and paid them 390 dinars. Maja bought 5 cookies and 4 juices and paid them 330 dinars. Determine the price of the cookie and the price of juice.

Task 2. Saša bought 3 bags of caramels and 2 bags of Negro candy, and Filip bought 2 bags of Ne- gro candy and 4 bags of caramels. If Saša has 120 candies in total and Filip 140, calculate how many caramels and how many Negro candies are in one bag.

Task 3. Goran measured the length and width of the yard. He used a stick and a rope to measure it. He measured that the length of the yard was equal to the length of 4 sticks and 6 ropes, and the width of 8 sticks and 3 ropes. If the length of the yard is 38 $\mathrm{m}$ and the width is $31 \mathrm{~m}$, calculate the length of the stick and rope.

\section{Appendix 3}

\section{Tasks used for work with students in the second phase of the study}

Task 1 . If a farmer sells 2 cows and 5 sheep, he will earn 80,000 dinars, and if he sells 3 cows and 2 sheep, he will earn 65,000 dinars. If we know that all cows are sold at the same price, as well as all sheep, at what price does the farmer sell one cow and at what price does he sell a sheep?

Task 2. Friends from the same class buy snacks every day. On Monday, they paid 230 dinars for two rolls, three yoghurts and five bagels. On Tuesday, they paid 340 dinars for two rolls, four yoghurts and eight bagels. On Wednesday, they paid 420 dinars for two rolls, five yoghurts and ten bagels. How much is a roll, how much is yoghurt, and how much is a bagel? The price of a product did not change that week.

Task 3. Wooden crayons are sold in a bookstore in three different box sizes - small, medium and large. On Monday, 4 small, 3 medium and 1 large box of crayons, or 70 crayons in total, were sold. On Tuesday, 2 small, 2 medium and 1 large box, or 50 crayons in total, were sold. A total of 65 crayons were sold on Wednesday, 1 small, 2 medium and 2 large boxes. How many crayons fit into a small box, how many into a medium size box and how many into a large box? 
Task 4. (Modified problem from Nine Chapters) A farmer planted three types of wheat on the field: good quality wheat, medium quality wheat and poor quality wheat.

On the first day, he took three bundles of good quality wheat, two bundles of medium quality wheat and one bundle of poor quality wheat, and got a total of $12 \mathrm{~kg}$ of grain.

On the second day, he took two bundles of good wheat, three bundles of medium wheat and one bundle of bad wheat, and got a total of $13 \mathrm{~kg}$ of grain.

On the third day he took one bundle of good wheat, two bundles of medium wheat and three of bad wheat, and in total he got $20 \mathrm{~kg}$ of grain.

How many kilograms of grain are obtained separately from one bundle of good, medium and bad wheat?

\section{Appendix 4.}

\section{Task on the test} after the second phase of the study

There are three types of cookies in the "Sweet Square" pastry shop: muffins, egg-custards and thumbprint cookies. All the cookies are packed in boxes so that all boxes with the same type of cookie have the same number of cookies in the package.

Pastry chef Mica had three customers in the morning. She sold one box of muffins, two boxes of egg-custards and two boxes of thumbprint cookies to the first customer, a total of 21 cookies. To the second customer, she sold one box of muffins, three boxes of egg-custards and three boxes of thumbprint cookies, or a total of 30 cookies. The third customer bought a total of 56 cookies, two boxes of muffins, five boxes of egg-custards and six boxes of thumbrint cookies.

How many cookies does each of the boxes of muffins, egg-custards and thumbprint cookies contain? 


\title{
Александра М. Михајловић
}

\author{
Ненад Р. Вуловић
}

\section{Милан П. Миликић}

Универзитет у Крагујевцу, Факултет педагошких наука у Јагодини, Србија

\section{ИЗГРАҚИВАҢЕ ПОЧЕТНИХ АЛГЕБАРСКИХ ПОЈМОВА У МЛАЂИМ РАЗРЕДИМА ОСНОВНЕ ШКОЛЕ ПРИМЕНОМ ФАНГЧЕНГ МЕТОДЕ}

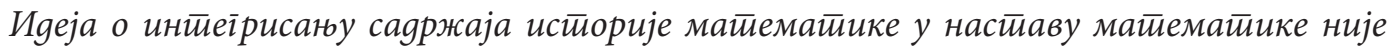

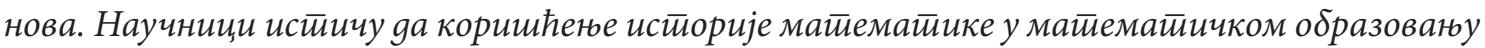

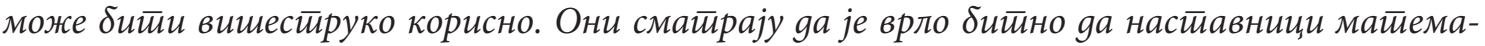

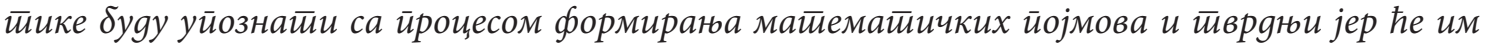

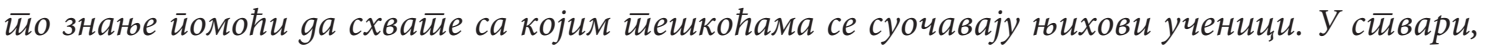

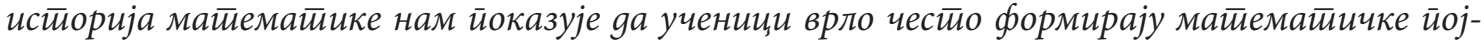
мове на сличан начин како је йо чиюено раније, йоком истиорије човечанстива. Главна сврха

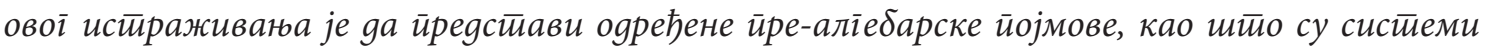
тинеарних јеgначина, у раgу са ученииима основне школе йомоћу јеgне сйаре кинеске метиоgе. У йрвом gелу раяа ӣриказана је древна кинеска Фаніичені мет̄оgа. Ова мейоgа ойисана је

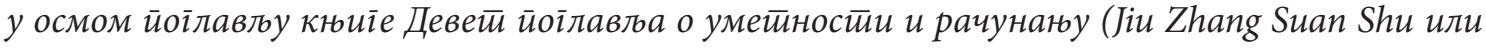
The Nine Chapters on the Art and Calculation), јеgноі og најзначајнијих и најуйицајнијих gела

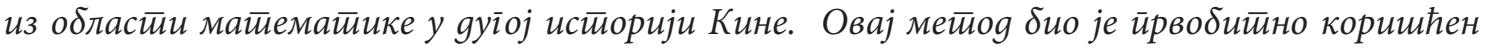
за решаване свакояневних живоитних ироблема, као шито је рачунане ирриноса иииринча, обрачунаване иена йојеgиних ӣроизвоgа, као и за бројане живойина. Фанчені метиоg је

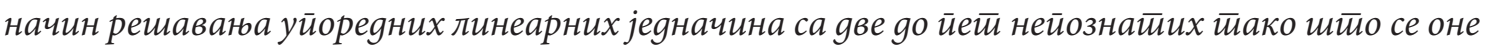

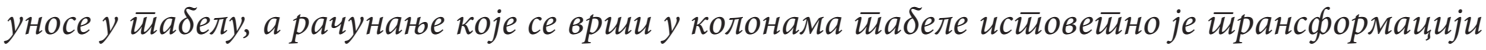
реgова у савременој майричној аліебри. У Србији, ученици йек у осмом разреgу основне школе уче како gа решавају системе тинеарних јеgначина. Циь овоі раgа је исиииииване

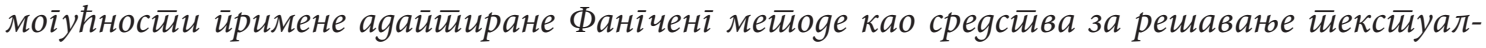
но заgайих ирроблема у раgу са ученицима чеивврйої разреgа основне школе. У gруїом gелу

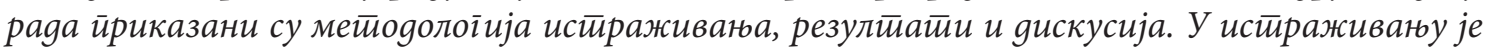

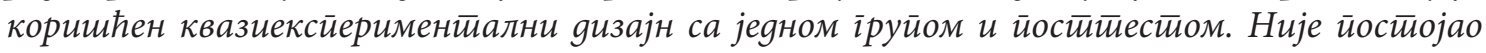
ойравgан разлоі gа уктучујемо и конитролну іруйу, јер не би било моїуће найравитии йо-

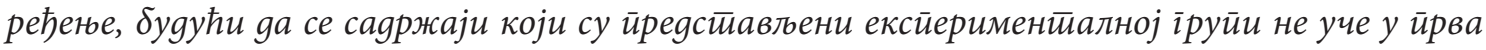

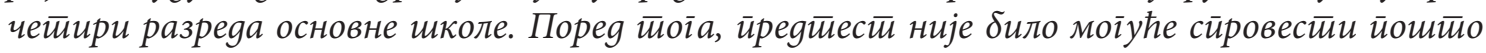
нико ов ученика није имао ирретхходно искустиво у вези са коришћенем йреgстиввеноі ме-

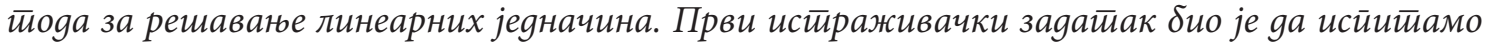

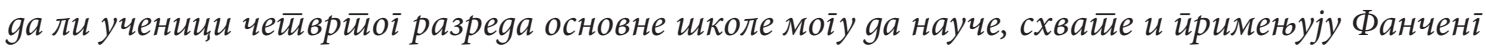

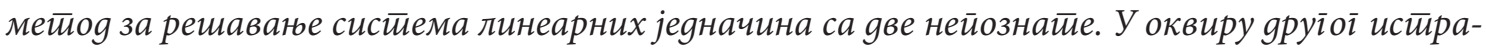

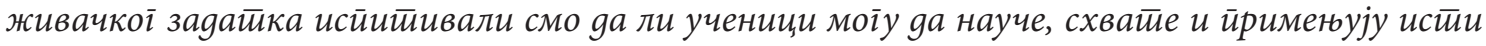

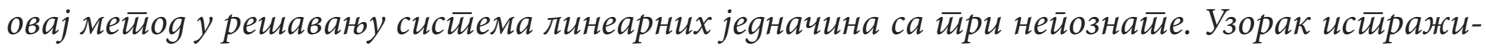




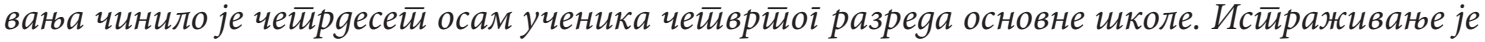
сиировеgено у gве фазе, а на крају сваке фазе рађен је йосийести. У йрвој фази учестивовали су сви учениии, док су у gруїој фази учестивовали само ученици који су йостииіли усиех на

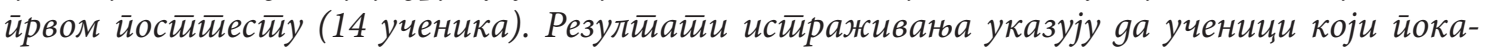

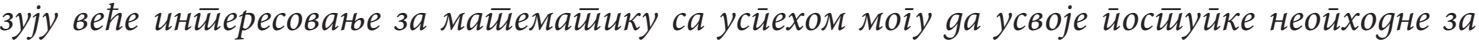
йримену Фаніччені метиоgе. Шйавише, већина ученика уме gа користии Фанчені метиоg без

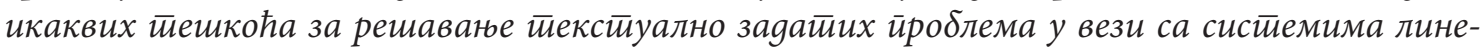

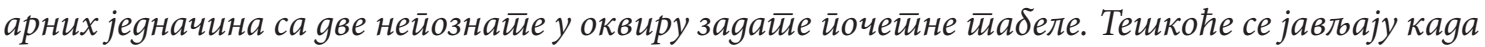

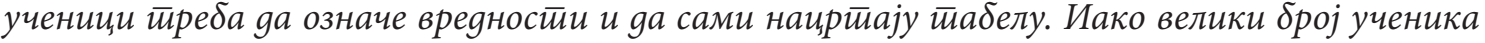

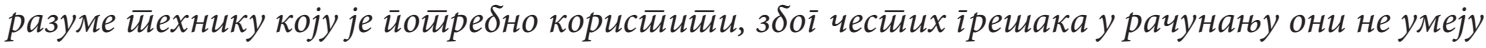

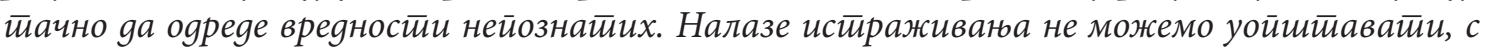

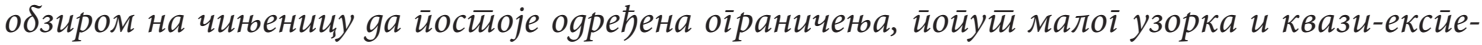

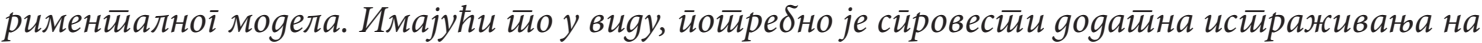
већем узорку ученика. С обзиром на йо gа не йосйоји велики број емйиријских исирраживана

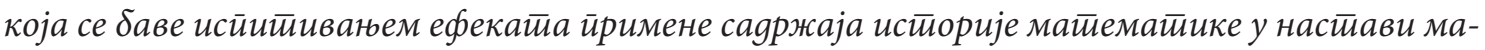
иематиике, верујемо gа овај раg йреgстиавља значајан доиринос овој областии. С йим у вези, у

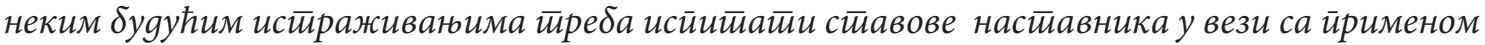

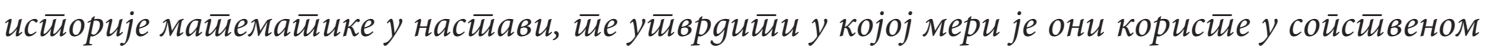
раgу са gецом, у које сврхе, у којим сеіменииима школскоі часа, као и да ли истиорија майемаиичке у довољној мери йобуђује инйересоване ученика.

Клучне речи: Фанічені метиоgа, систиеми тинеарних јеgначина, йочейна настиава ма-

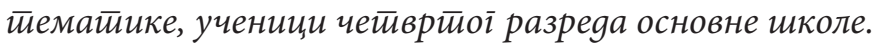

